OPEN ACCESS

ISSN 2580-7730 (online)

Edited by:

Andika Aliviameita

Reviewed by:

Yos Adi Prakoso

*Correspondence:

Viki Ayu Intan Permatasari

ayuviki7@gmail.com

Received: 4 Agustus 2020

Accepted: 9 September 2020

Published: 31 Desember 2020

Citation:

Permatasari VAl, Nurjanah MH and

Widodo WT (2020)

Effectiveness of

Ethanolic Extract of Aloe Vera

Leaves against Staphylococcus

aureus.

Medicra (Journal of Medical Laboratory Science/Technology).

3:2.

doi:

10.21070/medicra.v3i2.760

\section{Effectiveness of Ethanolic Extract of Aloe Vera Leaves against Staphylococcus aureus}

\section{Efektivitas Ekstrak Etanol Daun Lidah Buaya (Aloe vera) terhadap Staphylococcus aureus}

\author{
Viki Ayu Intan Permatasari*, Mutia Hariani Nurjanah, Wimbuh Tri Widodo \\ Analis Kesehatan, Sekolah Tinggi llmu Kesehatan Karya Putra Bangsa, Jalan Raya Tulungagung-Blitar KM 4, \\ Sumbergempol, Tulungagung, Jawa Timur, Indonesia
}

Since long ago Indonesia used nutritious plants as traditional medicines. Various types of plants in Indonesia can be used as alternative ingredients, one of which is aloe vera. Aloe vera contains saponin and anthraquinone, so aloe vera leaves function as antiseptic and antibacteria. Staphylococcus aureus is a gram positive coccus. This bacterium is often found as a normal germ flora in humans. Staphylococcus aureus can cause infections in humans and animals. This study aims to determine the effect of ethanolic extract of Aloe vera leaves in inhibiting Staphylococcus aureus by using maceration extract method. The concentrations used were $20 \%, 40 \%, 60 \%, 80 \%$ and $100 \%$ with positive control (erytromycin) and negative control (aquades). The inhibitory zone analysis is done using the table method. Test of ethanol extract of Aloe vera leaves in inhibiting Staphylococcus aureus produced inhibition zones at concentrations of $60 \%, 80 \%$ and $100 \%$ with average diameter of $6.94 \mathrm{~mm}, 6.22$ $\mathrm{mm}$ and $9.5 \mathrm{~mm}$. The conclusion of this research is the ethanolic extract of Aloe vera leaves can inhibit Staphylococcus aureus in high concentrations.

Keywords: Aloe vera leaves, Effectiveness, Ethanolic extract, Staphylococcus aureus

Sejak dahulu Indonesia mengenal dan memanfaatkan tumbuhan berkhasiat sebagai obat tradisional.Berbagai macam tanaman di Indonesia dapat digunakan sebagai bahan alternatif salah satunya yaitu tanaman lidah buaya.Lidah buaya (Aloe vera) memiliki kandungan didalamnya seperti saponin, antrakuinon, sehingga daun lidah buaya (Aloe vera) digolongkan sebagai pengobatan seperti antiseptik dan antibakteri. Staphylococcus aureus adalah bakteri kokus gram positif. Bakteri ini sering ditemukan sebagai kuman flora normal pada manusia. Bakteri Staphylococcus aureus dapat menjadi penyebab infeksi baik pada manusia maupun pada hewan. Penelitian ini bertujuan untuk mengetahui pengaruh ekstrak etanol daun lidah buaya (Aloe vera) dalam menghambat bakteri Staphylococcus aureus dengan menggunakan metode ekstrak maserasi. Pada uji daya hambat metode yang 
digunakan metode difusi cakram kertas. Konsentrasi yang digunakan mulai dari 20\%, 40\%, 60\%, 80\% dan 100\% dengan kontrol positif Erytromisin dan kontrol negatif aquades. Analisa zona hambat yang dilakukan dengan menggunakan metode tabel. Uji ekstrak etanol daun lidah biaya (Aloe vera) dalam menghambat bateri Staphylococcus aureus menghasilkan zona hambat pada konsentrasi $60 \%$, $80 \%$ dan $100 \%$ dengan rerata diameter sebesar $6,94 \mathrm{~mm} ; 6,22 \mathrm{~mm}$ dan $9,5 \mathrm{~mm}$. Dari hasil penelitian ini dapat disimpulkan bahwa ekstrak etanol daun lidah buaya (Aloe vera) dapat menghambat Staphylococcus aureus dalam konsentrasi tinggi.

Kata kunci: Ekstrak etanol daun lidah buaya (Aloe vera), Staphylococcus aureus 


\section{PENDAHULUAN}

Sejak dahulu Indonesia mengenal dan memanfaatkan tumbuhan yang berkhasiat sebagai obat untuk menanggulangi masalah kesehatan, jauh sebelum pelayanan kesehatan dengan obat-obatan modern dikenal oleh banyak masyarakat. Pengetahuan tentang pemanfaatan tumbuhan obat tersebut merupakan warisan budaya bangsa berdasarkan pengetahuan dan pengalaman yang diwariskan secara turun-temurun hingga kegenerasi sekarang, sehingga tercipta berbagai ramuan herbal yang merupakan ciri khas pengobatan tradisional Indonesia Rieuwpassa et al. (2011).

Berbagai macam tanaman di Indonesia dapat digunakan sebagai bahan alternatif obat, salah satunya adalah daun lidah buaya (Aloe vera). Daun lidah buaya berasal dari Ethiopia, Afrika. Salah satu antibiotik alternatf yang aman digunakan, efektif dan efisien. Tanaman lidah buaya ini sudah lama disebut sebagai tanaman obat dan juga biasa digunakan untuk menyembuhkan luka, perawatan kulit dan juga sebagai bahan baku industri farmasi Furmawanthi (2002).

Penyakit infeksi masih menjadi salah satu masalah kesehatan yang sering dihadapi. Bakteri penyebab infeksi salah satunya adalah Staphylococcus aureus. Bakteri Staphylococcus aureus sering ditemukan sebagai flora normal pada kulit, rambut, mulut, saluran pernafasan dan saluran pencernaan. Infeksi bakteri Staphylococcus aureus ditandai dengan kerusakan jaringan yang disertai abses bernanah.Beberapa penyakit infeksi yang disebabkan oleh Staphylococcus aureus adalah bisul, jerawat, impetigo dan infeksi luka. Bakteri Staphylococcus aureus dapat menyebabkan penyakit dengan dua cara, yaitu pertama secara langsung disebabkan oleh infeksi, kedua secara tidak langsung mengakibatkan keracunan makanan yang dapat disebakan oleh kontaminasi enterotoksin dari Staphylococcus aureus dan sindrom syok toksik (SST) Chantin and Suharto (1994).

Antibakteri merupakan zat yang berfungsi membunuh atau menghambat pertumbuhan dan reproduksi bakteri. Obat antibakteri yang sering kali digunakan dalam pengobatan penyakit infeksi bakteri umumnya merupakan sintetis kimia atau yang lebih dikenal sebagai antibiotik Natsir (2013). Penggunaan antibiotik tersebut hanya menimbulkan resistensi dan terjadinya efek samping seperti diare, alergi hingga toksik berbahaya yang lainnya Tammi et al. (2018), sehingga pengobatan tradisional dari bahan alam mulai dikembangkan karena kelebihan dari bahan alam yang tidak menimbulkan efek samping tetapi juga memiliki manfaat yang sama seperti antibakteri. Kandungan antibakteri lidah buaya (Aloe vera) dapat berpotensi sebagai bahan obat untuk menyembuhkan infeksi bakteri Staphylococcus aureus. Berdasarkan uraian di atas peneliti tertarik melakukan penelitian tentang uji ekstrak etanol daun lidah buaya (Aloe vera) dalam menghambat pertumbuhan bakteri Staphylococcus aureus.

\section{METODE}

Alat yang digunakan pada penelitian ini yaitu plate, erlen- meyer, beaker glass, batang pengaduk, ose bulat, pipet mikro, gelas ukur, tabung reaksi, sendok stainless. Bahan yang digu- nakan dalam penelitian ini yaitu etanol $70 \%$, lidah buaya, NB, Nutrient agar, spirtus, dan bakteri Staphylococcus aureus.

Sampel Stapylococcus aureus yang digunakan dalam penelitian ini didapatkan dari isolat klinis Universitas Brawijaya. Bakteri dimasukkan dalam plate berisi medium padat dan diinkubasi dalam suhu $37^{\circ} \mathrm{C}$ selama 24 jam. Bakteri yang tumbuh dalam medium padat kemudian di tumbuhkan lagi dengan media NB atau media cair kemudian diinkubasi dengan suhu $37^{\circ} \mathrm{C}$ selama 24 jam.

Sampel daun lidah buaya yang digunakan diperoleh dari Desa Mirigambar, Tulungagung, Jawa Timur. Daun lidah buaya di cuci bersih lalu di pisahkan antara kulit dan gel. Gel lidah buaya ditimbang sebanyak 125 gram, kemudian gel lidah buaya dihaluskan dan dilakukan proses perendaman menggunakan pelarut etanol $70 \%$ sebanyak $250 \mathrm{ml}$ dengan wadah yang tertutup dan terlindungi dari cahaya selama 24 jam, kemudian disaring dengan wadah penampung dan hasil penyaringan diuapkan dengan menggunakan oven dengan suhu $60^{\circ} \mathrm{C}$. Hasil lidah buaya (Aloe vera) yang sudah kering di ambil dan dibuat konsentrasi yang diinginkan.

Pada metode pembuatan konsentrasi ekstrak etanol daun lidah buaya menggunakan sebanyak 5 tahap yaitu 20\%, 40\%, $60 \%, 80 \%$, dan $100 \%$. Ekstrak etanol lidah buaya yang telah dioven di timbang sesuai konsentrasi yang akan dibuat yaitu, konsentrasi $20 \%$ dengan menimbang 0,2 gram di larutkan dalam aquades $0,8 \mathrm{ml}$. Konsentrasi $40 \%$ dengan menimbang 0,4 gram dilarutkan dalam aquades $0,6 \mathrm{ml}$. Konsentrasi $60 \%$ dengan menimbang 0,6 gram dilarutkan dalam aquades $0,4 \mathrm{ml}$. Konsentrasi $80 \%$ dengan menimbang 0,8 gram dilarutkan dalam aquades $0,2 \mathrm{ml}$.

Pengujian daya hambat ekstrak etanol daun lidah buaya (Aloe vera) dilakukan dengan cara menyiapkan media NA dengan menimbang sebanyak 2,6 gram dalam $130 \mathrm{ml}$ aquades. Dituang kedalam plate dan dibiarkan dingin hingga memadat. Selanjutnya diinokulasikan bakteri uji pada permukaan media dengan cara memipet bakteri lalu diratakan dengan ose bulat. Kemudian paper disk yang direndam selama 15 menit pada masing-masing konsentrasi $0 \%, 20 \%, 40 \%, 60 \%, 80 \%, 100 \%$, diletakkan dipermukaan media secara aseptis. Diinkubasi pada suhu $37^{\circ} \mathrm{C}$ selama 24 jam lalu diamati dan diukur zona hambat yang terbentuk.

\section{HASIL DAN PEMBAHASAN}

Metode maserasi merupakan metode yang digunakan dalam membuat ekstrasi secara sederhana. Penelitian ini bertujuan untuk mengetahui ekstrak etanol daun lidah buaya (Aloe vera) dalam menghambat pertumbuhan bakteri Staphylococcus aureus dengan cara difusi. Cara ini digunakan untuk men- 
gukur diameter zona hambat yang terbentuk dengan menggunakan pengukur Yusitta (2018) .

Dari penelitian ini dapat ditentukan dengan melakukan pengamatan. Kemudian diameter zona hambat tersebut dikategorikan sebagai kekuatan daya antibakterinya. Klasifikasi respon hambatan pertumbuhan bakteri menurut Pratama (2005) seperti ditunjukkan pada Tabel 1 . Sedangkan hasil zona hambat Staphylococcus aureus pada ekstrak etanol daun lidah buaya (Aloe vera) dengan konsentrasi 20\%, 40\%, 60\%, 80\%, 100\% ada pada Tabel 2 .

Berdasarkan hasil dari penelitian yang telah dilakukan, dapat dilihat bahwa ekstrak etanol daun lidah buaya (Aloe vera) dapat menghambat pertumbuhan bakteri Staphylococcus aureus. Ini dapat dilihat dengan adaya zona hambat yang terbentuk. Besar kecilnya zona hambat yang terbentuk dipengaruhi adanya ekstrak yang diberikan. Hal ini terlihat pada rata-rata diameter zona hambat pertumbuhan bakteri pada masing-masing perlakuan.

Rata-rata jumlah diameter zona hambat bakteri yang tumbuh dengan pemberian ekstrak etanol daun lidah buaya $60 \%$ adalah $6,94 \mathrm{~mm}$, sedangkan pada konsentrasi $80 \%$ adalah 7,55 $\mathrm{mm}$ dan pada konsentrasi $100 \%$ adalah $9,5 \mathrm{~mm}$. Sehingga di bandingkan dengan tabel hasil rata-rata yang diperoleh menunjukkan bahwa daya hambat yang dimiliki masih pada kategori sedang, karena hasil rata-rata konsentrasi 60\%,80\% dan 100\% masih <10 mm. Pada konsentrasi $20 \%$ dan $40 \%$ tidak terbentuk zona hambat hal ini kemungkinan dikarenakan kontaminasi udara saat membuka cawan yang terlalu lebar.

Berdasarkan Tabel 2 menunjukkan bahwa semakin meningkatnya konsentrasi maka hambatnya semakin besar. Hal ini sesuai dengan Brooks et al. (2007), bahwa efektivitas suatu zat antimikroba dipengaruhi oleh konsentrasi zat yang diberikan. Meningkatnya konsentrasi pada ekstrak mengakibatkan tingginya kandungan zat aktif yang berfungsi sebagai antimikroba sehingga dapat menghambat pertumbuhan bakteri Schelegel (1994) . Menurut Ajizah (2004), selain faktor dari konsentrasi yang dibuat, jenis bahan antimikroba juga dapat menentukan kemampuan dalam menghambat pertumbuhan bakteri.

Ekstrak daun lidah buaya mampu menghambat pertumbuhan bakteri Staphylococcus aureus karena memiliki kandungan bioaktif yang berfungsi sebagai bahan antibakteri. Kandungan zat yang terdapat pada daun lidah buaya (Aloe vera) yaitu saponin, antrakuinon dan tannin diketahui banyak khasiat bagi dunia pengobatan. Tannin merupakan senyawa aktif metabolit sekunder yang memiliki banyak kasiat yaitu sebagai antibakteri dan anti oksi- dan. Saponin diketahui mempunyai efek antimikroba karena saponin merupakan zat aktif yang dapat meningkatkan permeabilitas sel bakteri sehingga bakteri tersebut akan mengalami hemolisis sel.
Antrakuinon merupakan senyawa fenolik yang ditemukan didalam getah. Antrakuinon yang terdapat pada tumbuhan lidah buaya bekerja seperti tetrasiklin yaitu menghambat sintesis protein pada bakteri sehingga tidak dapat tumbuh dalam media yang diberi konsentrasi ekstrak daun lidah buaya. Menurut penelitian Pandey and Mishra (2010), ekstrak daun lidah buaya dapat menghambat bakteri gram positif Staphylococcus aureus. Berdasarkan data pada hasil penelitian diketahui bahwa pemberian ekstrak daun lidah buaya mampu menghambat pertumbuhan bakteri Staphylococcus aureus.

\section{KESIMPULAN}

Uji ekstrak daun lidah buaya (Aloe vera) memiliki pengaruh dalam menghambat pertumbuhan bakteri Staphylococcus aureus. Semakin tinggi konsentrasi ekstrak etanol daun lidah buaya (Aloe vera) maka semakin besar diameter zona hambat bakteri Staphylococcus aureus.

Konsentrasi terendah dari ekstrak daun lidah buaya (Aloe vera) yang dapat menghambat pertumbuhan bakteri Staphylococcus aureus pada konsentrasi $40 \%$ dan 60\% masih buruk dalam menghambat, sedangkan konsentrasi ekstrak daun lidah buaya (Aloe vera) yang paling efektif dapat menghambat pertumbuhan bakteri Staphylococcus aureus dengan katergori kuat pada konsentrasi $80 \%$ dan $100 \%$.

\section{KONTRIBUSI PENULIS}

Penulis pertama berperan dalam pengumpulan data, sedangkan penulis kedua dan ketiga membantu dalam penyusunan artikel.

\section{PENDANAAN}

Penelitian ini dibiayai secara mandiri oleh peneliti.

\section{UCAPAN TERIMA KASIH}

Terimakasih kepada para rekan yang membantu dalam penelitian ini 
TABEL 1 / Klasifikasi Respon Hambatan Pertumbuhan Bakteri

\begin{tabular}{ll}
\hline Diameter Zona Hambat & Respon Hambat Pertumbuhan \\
$>20 \mathrm{~mm}$ & Sangat kuat \\
$10-20 \mathrm{~mm}$ & Kuat \\
$5-10 \mathrm{~mm}$ & Sedang \\
$<5 \mathrm{~mm}$ & Lemah \\
\hline
\end{tabular}

TABEL 2 / Hasil Zona Hambat Staphylococcus aureus

\begin{tabular}{lllll}
\hline Konsentrasi & Percobaan 1 & Percobaan 2 & Percobaan 3 & Rata-rata \\
$20 \%$ & Negatif & Negatif & Negatif & Negatif \\
$40 \%$ & Negatif & Negatif & Negatif & Negatif \\
$60 \%$ & $10.32 \mathrm{~mm}$ & $5.25 \mathrm{~mm}$ & $5.25 \mathrm{~mm}$ & $6.94 \mathrm{~mm}$ \\
$80 \%$ & $6.65 \mathrm{~mm}$ & $8.4 \mathrm{~mm}$ & $7.6 \mathrm{~mm}$ & $7.55 \mathrm{~mm}$ \\
$100 \%$ & $6.65 \mathrm{~mm}$ & 11.04 & 10.81 & $9.5 \mathrm{~mm}$ \\
Kontrol (+) & $11.00 \mathrm{~mm}$ & $11.00 \mathrm{~mm}$ & $12.00 \mathrm{~mm}$ & $11.30 \mathrm{~mm}$ \\
Kontrol (-) & Negatif & Negatif & Negatif & Negatif \\
\hline
\end{tabular}

\section{REFERENSI}

Ajizah, A. (2004). Sensivitas Salmonella typium Terhadap Ekstrak Daun Pisidium guajava L. . Bioscientiae 1, 31-38.

Brooks, G. F., Butel, J. S., Carrol, K. C., and Morse, S. A. (2007). Mikrobiologi Kedok teran (Jakarta: EGC).

Chantin, A. and Suharto (1994). Sterilisasi dan Desinfektan dalam Mikrobiologi Kedokteran, Edisi Revisi(Jakarta: Binarupa Aksara).

Furmawanthi, I. (2002). Khasiat \& Manfaat Lidah Buaya Si Tanaman Ajaib. (Jakarta: Argo Media Pustaka), 1-21.

Natsir, N. A. (2013). Pengaruh Ekstrak Daun Lidah Buaya (aloe vera) sebagai penghambat pertumbuhan Bakteri Staphylococcus aureus. $110-112$.

Pandey, R. and Mishra, A. (2010). Antibacterial Activities of Crude Extract of Aloe barbadensis to Clinically Isolated Bacterial Pathogens. Applied Biochemistry and Biotechnology 160, 1356-1361. doi: 10.1007/s12010009-8577-0.

Pratama, M. R. (2005). Pengaruh Ekstrak Serbuk Kayu Siwak (Saivadora persica) Terhadap Pertumbuhan Bakteri Streptococcus mutan dan Staphylococcus aureus Dengan Metode Difusi Agar.

Rieuwpassa, I. E., Rahmat, and Karlina (2011). Daya Hambat Ekstrak Aloe vera terhadap pertumbuhan Staphylococcus aureus. Dentofasial 10, 65-70.

Schelegel, H. G. (1994). Mikrobiologi Umum (Yogyakarta: Gajah Mada UniversityPress).

Tammi, A., Apriliana, E., Sholeha, T. U., and Ramadhian, M. R. (2018). Inhibition Potential of Bay Leaf Extract (Syzygium polyanthum [Wight.] Walp.) as Antibacterial to Staphylococcus aureus In Vitro. $J$ Agromedicine Unila 5, 562-566.

Yusitta, Y. (2018). Efektivitas Ekstrak Daun Lidah Buaya terhadap Pertumbuhan Staphylococcus aureus dengan metode Difusi.

Conflict of Interest Statement: The authors declare that the research was conducted in the absence of any commercial or financial relationships that could be construed as a potential conflict of interest.

Copyright (C) 2020 Permatasari, Nurjanah, and Widodo. This is an openaccess article distributed under the terms of the Creative Commons Attribution License (CC BY). The use, dis- tribution or reproduction in other forums is permitted, provided the original author(s) and the copyright owner(s) are credited and that the original publication in this jour- nal is cited, in accordance with accepted academic practice. No use, distribution or reproduction is permitted which does not comply with these terms. 